Transfusion Medicine
and Hemotherapy
Review Article · Übersichtsarbeit

Transfus Med Hemother 2009;36:263-272

DOI: $\underline{10.1159 / 000223098}$
Received: February 17, 2009

Accepted: May 14, 2009

Published online: June 25, 2009

\title{
MALDI-TOF MS in Prenatal Genomics
}

\author{
Xiao Yan Zhong ${ }^{a}$ Wolfgang Holzgreve ${ }^{b}$ \\ a Laboratory for Prenatal Medicine and Gynaecological Oncology, University Women's Hospital /Department Research, \\ University of Basel, Switzerland

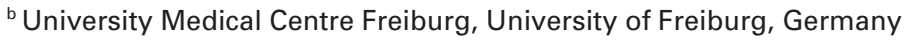

\section{Key Words}

Prenatal diagnosis - Non-invasive prenatal diagnosis . Matrix-assisted laser desorption/ionization-time of flight mass spectrometry - MALDI-TOF MS .

Homogenous MassEXTEND · hME .

Single allele base extension reaction - SABER .

Aneuploidy · Monogenic disorder

\section{Summary}

Prenatal diagnosis aims either to provide the reassurance to the couples at risk of having an affected child by timely appropriate therapy or to give the parents a chance to decide the fate of the unborn babies with health problems. Invasive prenatal diagnosis (IPD) is accurate, however, carrying a risk of miscarriage. Noninvasive prenatal diagnosis (NIPD) has been developed based on the existing of fetal genetic materials in maternal circulation; however, a minority fetal DNA in majority maternal background DNA hinders the detections of fetal traits. Different protocols and assays, such as homogenous MassEXTEND (hME), single allele base extension reaction (SABER), precise measuring copy number variation of each allele, and quantitative methylation and expression analysis using the high-throughput sensitive matrix-assisted laser desorption/ionization-time of flight mass spectrometry (MALDI-TOF MS), allow NIPD for single gene disorders, fetal blood group genotyping and fetal aneuploidies as well as the development of fetal gender-independent biomarkers in maternal circulation for management of pathological pregnancies. In this review, we summarise the use of MALDI-TOF MS in prenatal genomics.

\section{Schlüsselwörter}

Pränatale Diagnostik · Noninvasive pränatale Diagnostik · «Matrix-assisted laser desorption/ionization-time of flight mass spectrometry" · MALDI-TOF MS . "Homogenous MassEXTEND" - hME . "Single allele base extension reaction» . SABER . Aneuploidie · Monogenetische Erkankung

\section{Zusamenfassung}

Die pränatale Diagnostik zielt darauf ab, entweder Paaren, bei denen das Risiko eines betroffenen Kindes besteht, die Rückversicherung für eine rechtzeitige angemessene Therapie zu geben, oder Eltern die Chance zu geben über das Schicksal von ungeborenen Kindern mit schwerwiegenden gesundheitlichen Einschränkungen zu entscheiden. Die invasive pränatale Diagnostik (IPD) ist präzise, birgt aber das Risiko einer Fehlgeburt. Die noninvasive pränatale Diagnostik (NIPD) wurde auf der Grundlage des vorhandenen fetalen genetischen Materials im mütterlichen Blutkreislauf entwickelt. Allerdings erschwert die geringe Menge fetaler DNA innerhalb der großen Menge an mütterlicher DNA den Nachweis von fetalen Charakteristika. Verschiedene Protokolle und Assays - z.B. "homogenous MassEXTEND» (hME), "single allele base extension reaction» (SABER), präzise Messung der Variation der Kopienzahl eines jeden Allels und quantitiative Methylierung und Expressionsanalyse mithilfe der "matrix-assisted laser desorption/ionization-time of flight mass spectrometry" (MALDI-TOF MS) - ermöglichen eine NIPD von einzelnen Genstörungen, fetaler Blutgruppengenotypisierung und fetalen Aneuploidien ebenso wie die Entwicklung von fetalen, geschlechtsunabhängigen Biomarkern in der mütterlichen Zirkulation für das Management pathologischer Schwangerschaften. Die vorliegende Arbeit gibt einen Überblick zur Verwendung von MALDI-TOF MS in der pränatalen Diagnostik.

\section{KARGER}

Fax +497614520714

Information@Karger.de

www.karger.com (c) 2009 S. Karger GmbH, Freiburg

Accessible online at:

www.karger.com/tmh 


\section{Introduction}

Approximately 2-4 out of 100 babies have birth defects defined as abnormalities of structure, function or body metabolism, which is a serious and costly public health problem as well as a family problem when combining medical and social factors $[1,2]$. A routine prenatal diagnostic test to detect birth defects in the fetus or embryo before it is born has been introduced for either performing a timely appropriate treatment or giving the parents a chance to decide the fate of the unborn babies with health problems [3,4]. The most common indication for prenatal diagnosis is advanced maternal age at risk of having babies with chromosome abnormalities [5, 6]. The monogenic disorders are also a common reason why couples opt for prenatal genetic testing [7]. Conventional methods for prenatal genetic testing are based on invasive procedures, such as chorionic villus sampling, amniocentesis and cord blood sampling, to obtain fetal genetic materials for prenatal genetic analysis $[8,9]$. The invasive procedures involve needles being inserted into the placenta or cord, which is associated with a risk of miscarriage to the fetus, thus, resulting in physical and mental burden to the affected pregnant women as well as their family members [10-14]. Because of this, many medical scientists made efforts to move toward less invasive procedures for prenatal diagnosis. Several non-invasive screening methods, such as ultrasonography and maternal serum screen, have been developed to evaluate the risk of carrying an aneuploidic fetus; however, a final definitive diagnosis regarding the pathological factor cannot be made through those non-invasive screen approaches $[15,16]$. Additionally, those approaches are not useful for the prenatal diagnosis of fetal monogenic disorders [17-20].

\section{Risk-Free Non-Invasive Prenatal Diagnosis}

The discovery of fetal cells in the maternal circulation seemed to offer a new opportunity for a risk-free, non-invasive prenatal diagnosis (NIPD) [21]. The advantage of fetal cells in maternal blood for analysis of chromosome abnormalities is that fetal cells have complete fetal genetic features [22]. Several fetal cell types, such as fetal leucocytes, fetal nucleated red blood cells (erythroblasts) and placental trophoblasts, have been found in maternal circulation and were suggested as a potential source of fetal genetic materials for prenatal diagnosis obtainable from maternal blood [23]. Due to the limited lifespan and relative higher frequency of fetal erythroblasts in the fetus in early gestation, this type of cells has been mostly studied for NIPD [24, 25]. Scientists attempted in the past decades to isolate fetal erythroblasts from maternal circulation for prenatal diagnosis using different methods, such as fluorescence-activated cell sorting(FACS)-based positive selection and magnetic-activated cell sorting(MACS)-based positive selection; however, the isolation procedures were tedious to perform, and a significant proportion of enriched erythroblasts were of maternal origin [26, 27]. In addition, rare fetal cells, mostly with apoptotic properties circulating in maternal blood, have made genetic analysis difficult and clinical application unavailable [28].

The discovery of circulating cell-free fetal DNA (cff-DNA) in maternal plasma has opened new opportunities for NIPD [29]. Compared to fetal cells in maternal circulation, cff-DNA in maternal plasma could be detected earlier, more frequently, and in greater amounts than the cellular species [30-33]. The clearance of cff-DNA in maternal circulation is very rapid [34], and therefore it is a suitable target for prenatal diagnosis without being biased by any previous pregnancies. Fetal genetic materials in maternal circulation, such as the fetal sex determining region of $\mathrm{Y}$ (SRY) and the fetal RhD in the circulation of RhD-negative pregnant women [35], which are absent from the maternal genome, can be easily determined using real-time PCR. Risk-free prenatal identification of fetal gender regarding X-linked disorders and fetal RhD status for the management of RhD-negative pregnant women using cff-DNA has been successfully applied for clinical use $[36,37]$. However, the fact that cff-DNA circulating in maternal plasma is a minor component within the total DNA being released from maternal blood cells makes the prenatal diagnosis of fetal chromosome abnormalities crucially difficult [38, 39]. Paternal inherited monogenic disorders with subtle mutations in minor fetal components, which only differ slightly in the predominated maternal wild-type DNA of interest, also offers a considerable challenge for NIPD using cff-DNA in maternal circulation [40]. A precise quantitative and qualitative molecular biological technique using fetal genetic materials circulating in maternal blood seems to be in demand for sensitively and specifically detecting fetal single nucleotide polymorphism (SNP) as well as fetal trisomy.

\section{MALDI-TOF MS}

Matrix-assisted laser desorption/ionization-time of flight mass spectrometry (MALDI-TOF MS) was initially developed for the application in the analysis of proteins and peptides. Later this technology found its great use for sequence variation analysis in the post-genome sequencing era [41, 42]. Based on this platform, Sequenom (San Diego, CA, USA) initiated a company for developing high-throughput qualitative and quantitative analysis of SNPs through an accurate and direct measurement of the molecular weights of the nucleic acid products, at about 100 times higher resolution than capillary sequencing $[43,44]$. The approach combines PCR, base extension reaction and MALDI-TOF MS analysis. The DNA sequence of interest is amplified by PCR. An extension primer designed by homogenous MassEXTEND (hME) software adds to the extension reaction. DNA polymerase along with a mixture of terminator nucleotides enables extension of the 
Fig. 1. MALDITOF MS in NIPD for monogenic disorders. A Two forms of autosomal inheritance in monogenic disorders. B Two methods: hME and SABER. C MALDI-TOF-MS Compact System. D Allele specific extension products (mutant and/or wildtype) detected by MALDI-TOF MS.

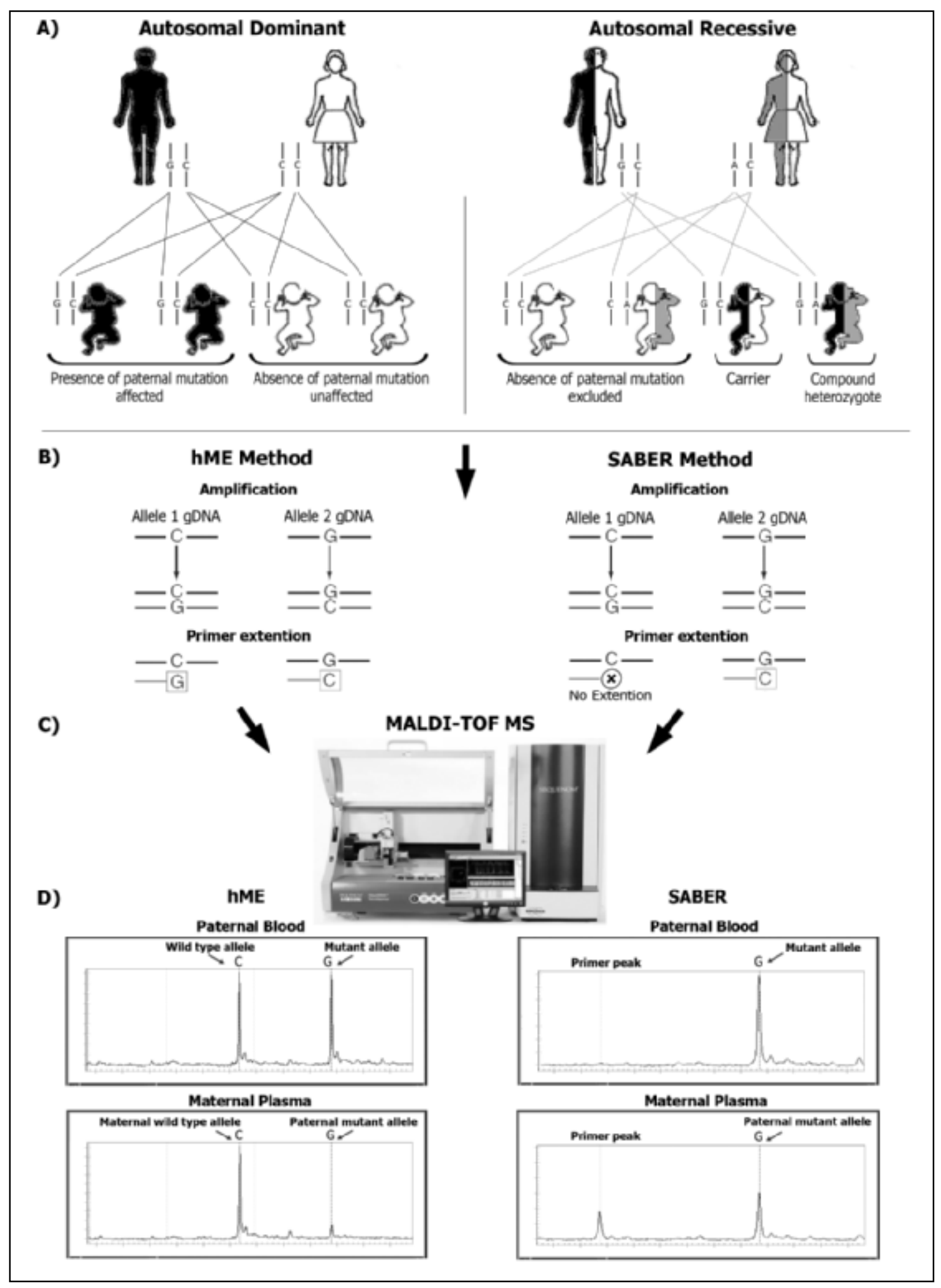

third primer specifically to the polymorphic or mutation site and generates allele-specific extension products from wildtype and mutant DNA (fig. 1). Unspecific amplified PCR products cannot serve as a template in the extension reaction. Each extension product has a unique molecular mass, resulting in separated signals analysed by MALDI-TOF MS through the mass/charge ratio to differentiate between alleles differing by as little as one base robustly [45]. Less than $5 \%$ mutant DNA in a more than $95 \%$ wild-type DNA background could be precisely discriminated [46]. Recently, multiplexing PCR and extension reactions in a single well with high automation is available to increase the high-throughput capacity and re- 
duce cost for genotyping [47]. The high-throughput sensitive MALDI-TOF MS has been successfully used for detecting fetal single nucleotide mutations in maternal wild-type DNA allowing for NIPD of genetic diseases [48, 49]. For NIPD, to increase the sensitivity of detection of minority fetal DNA in majority maternal DNA molecules, Ding et al. [48] modified the hME protocol and developed a single allele base extension reaction (SABER) followed by analysis by MALDI-TOF MS. Compared to the hME, which involves base extension of both mutant and wild-type alleles, SABER extends only fetalspecific mutant alleles $[49,50]$.

\section{MALDI-TOF MS in Non-Invasive Prenatal Diagnosis for Monogenic Disorders Using cff-DNA}

Figure 1A illustrates the strategies of NIPD for the two forms of inherited disorders - autosomal dominant and autosomal recessive inheritances.

Autosomal dominant paternally inherited genetic traits absent in the maternal genome can be examined for NIPD using cff-DNA in maternal circulation. For the autosomal dominant inheritance, if a father is affected, the NIPD can be applied to identify all of his offspring either affected with presence of paternally inherited mutation or unaffected with absence of paternally inherited mutation in maternal circulation. Achondroplasia is a type of autosomal dominant genetic disorder [51]. An autosomal dominant mutation in the fibroblast growth factor receptor gene 3 (FGFR3) causes an abnormality of cartilage formation and leads to several shortened bones [52]. In our group, two couples were enrolled for NIPD of achondroplasia. Using MALDI-TOF with SABER, the fetal mutation on FGFR3 was detected in maternal circulation in the two affected cases [53]. The successful NIDP gave the parents the chance to prepare for their babies being short-limbed dwarfism. Since cff-DNA sequences in maternal circulation are smaller than maternal ones, the selection of small cff-DNA fragments by size fractionation by agarose gel electrophoresis leads to the enrichment of cff-DNA sequences. In our study for NIPD of achondroplasia, Li et al. [53] compared the MALDI-TOF MS approach with and without size fractionation performed before the PCR. The size fractionation gave a stronger signal for the fetal allele.

For NIPD of autosomal recessive inherited genetic traits, a strategy has been developed to exclude the compound heterozygous conditions through the detection of cff-DNA in maternal plasma [54]. An affected fetus with a compound heterozygous condition harbours two different mutations, one from the father and another one from the mother (fig. 1A). An absence of a paternal mutant allele or presence of paternal wildtype allele in maternal plasma indicates that the fetus has not inherited the mutated paternal allele and thus cannot manifest such disorder $[55,56]$.
Thalassaemias are types of autosomal recessive hereditary anaemias due to defects in haemoglobin production caused mainly by mutations. More than 300,000 infants with major thalassaemias are born every year, and it is associated with considerable morbidity and mortality. The WHO declares these disorders a major public health problem worldwide. As an important step in the prevention of severe $\beta$-thalassaemia, the prenatal detection of homozygous and compound heterozygous pregnancies is used [57-59].

More than $200 \beta$-thalassaemia mutations have been reported [60]. Ding et al. [49] evaluated the use of MALDI-TOF MS with hME and SABER for the discrimination of fetal point mutations in maternal plasma to develop a NIPD for the exclusion of thalassaemia major in four most common $\beta$-thalassaemia mutations in Southeast Asia: CD 41/42 -CTTT, IVS2 $654(\mathrm{C} 3 \mathrm{~T})$, nt $-28(\mathrm{~A} \rightarrow \mathrm{G})$, and CD $17(\mathrm{~A} \rightarrow \mathrm{T})$. Eleven pregnancies between 7 and 21 weeks of gestation at risk for $\beta$ thalassaemia major, in which the involved father and mother carried different $\beta$-thalassaemia mutations, were recruited for the exclusion of fetuses with compound heterozygous. Six out of 11 cases showed the absence of the paternal mutant allele in maternal circulation, suggesting that the babies do not manifest the thalassaemia major. Detection of the paternal mutation in maternal plasma by using the SABER protocol was completely concordant with the fetal genotype determined by invasive prenatal diagnosis, whereas the hME protocol gave two false-negative results, implying that the SABER protocol seemed to be more sensitive than the hME protocol.

For NIPD of the thalassaemia major, in our group, we first developed a simple, fast and cost-effective allele-specific realtime PCR to detect the presence of the paternal mutant fetal allele in maternal circulation. Four common $\beta$-thalassaemia mutations in the Mediterranean region, IVSI-1, IVSI-6, IVSI110 and codon 39, were analysed in the study. Cff-DNA was enriched by size fractionation on gel electrophoresis to enhance the sensitivity of the approach, and a peptide-nucleicacid clamp, which was designed to suppress amplification of the normal maternal allele, was used to increase the specificity of the PCR reaction. An overall sensitivity of $100 \%$ and a specificity of $93.8 \%$ in the samples with sufficient amount and quality of DNA could be achieved in a cohort study of 32 cases [40]. Recently, we built an international network based on high-throughput of MALDI-TOF MS to evaluate the use of the system for NIPD in $\beta$-thalassaemia. The preliminary data shows the feasibility for the exclusion of thalassaemia major in 6 most common $\beta$-thalassaemia mutations, IVS1-1, IVS1-6, IVS1-110, IVS2-745, CD39 and CD44, in the Mediterranean region (data not shown).

$\mathrm{X}$-linked diseases are also single gene disorders caused by mutations on the $\mathrm{X}$ chromosome. In $\mathrm{X}$-linked recessive conditions, e.g. red-green colour blindness, haemophilia and the Duchenne and Becker forms of muscular dystrophy, a normal female carrier passes mutations on an X chromosome to $50 \%$ of her daughters normally being a carrier and to $50 \%$ 
of her sons being affected. The strategy of prenatal diagnosis of X-linked recessive conditions is to exclude the female offspring from the risk of the disease. Identification of fetal gender regarding prenatal diagnosis for X-linked disorders can be performed by ultrasonography, which is available from 14 weeks of gestation. However, fetal SRY, which is Y-chromosome-specific and absent in the maternal genome, is detectable in maternal plasma from the 5th gestational week using standardized simple and robust real-time PCR. The approach has been successfully translated to clinical routine application. An alternative NIPD of fetal gender can be performed using MALDI-TOF MS. Ding et al. [48] evaluated the use of MALDI-TOF MS to detect fetal SRY in maternal plasma. When the input DNA containing more than one copy of SRY per reaction, a $100 \%$ accuracy could be achieved to identify fetal gender using the MS approach.

\section{MALDI-TOF in NIPD of Fetal Blood Group Genotyping}

The $\mathrm{Rh}$ blood group system contains 5 main $\mathrm{Rh}$ antigens $(\mathrm{C}$, c, D, E and e) on the surface of human red blood cells. RhD is the most important antigen causing haemolytic disease of newborn (HDN) in pregnancies. A routine antenatal anti$\mathrm{D}$ prophylaxis for $\mathrm{RhD}$-negative pregnant women has been recommended; however, this immunoprophylaxis is cost-consuming and has risks associated with administration of blood products, possibly resulting in viral infection [61-63]. If a partner of an $\mathrm{RhD}$-negative pregnant woman is $\mathrm{RhD}$-positive heterozygous, $50 \%$ of their offspring will be $\mathrm{RhD}$-negative and will be at no risk for immunization. Therefore, the health service is unnecessary for those cases. IPD for identification of fetal RhD status, with the aim of managing RhD-negative pregnant women, might lead to miscarriage and immunization [64-66]. The NIPD of the fetal RhD status using cff-DNA in maternal blood by real-time PCR is well established and already offered as a clinical service in a number of countries [67]. A gold standard for diagnosis can be achieved [68]. In our group, we also evaluated the feasibility of using MALDITOF MS to detect fetal RhD sequence in maternal circulation from RhD-negative pregnant women [69]. Primers were designed to amplify fetal RhD exon 7 . The presence or absence of the fetal RhD exon 7 was determined by MALDI-TOF MS. With SABER protocol, we were able to detect $15 \mathrm{pg}$ of $\mathrm{RhD}$ positive genomic DNA in a background of $585 \mathrm{pg}$ of RhDnegative genomic DNA corresponding to the concentration of cff-DNA in maternal plasma. A total of 178 plasma samples from pregnant women were analysed in a blinded manner by the approach. A sensitivity of $96.1 \%$ and a specificity of 96.1\% could be achieved, which is comparable with those by quantitative real-time PCR [69]. However, the MALDI-TOF MS promises high-throughput detections of up to 384 samples per single chip, which can be applied for large-scale analysis. In addition, the multiplexing PCR and extension reactions in a single well with high automation offers the possibility to detect variant $\mathrm{Rh}$ alleles, to increase the high-throughput capacity, and to reduce cost for blood group genotyping.

The Kell blood system is defined by a group of antigens on the surface of human red blood cells. KEL1 and KEL2 are the most common alleles in the Kell blood system based on a single base substitution ( $\mathrm{C}$ to $\mathrm{T}$ ) in exon 6 of the Kell gene $[70,71]$. The KEL1 antigen, found in $9 \%$ of Caucasians, is the second most important antigen causing HDN in pregnancies $[72,73]$. We developed the MALDI-TOF MS-based SABER to examine the fetal KEL1 gene from 32 KEL1-negative pregnant women with a median gestation of 21 weeks using cffDNA in maternal plasma. The extension primer was designed only for extending the mutant allele $\mathrm{T}$ site from the fetus. After PCR amplification and SABER procedure, following MALDI-TOF MS analysis, we were able to detect the fetal KEL1 allele in 11 of the 13 KEL1-positive samples. No falsepositive results were scored. The paternal KEL1 allele could be correctly determined in $94 \%$ of cases (30/32) [74].

Human platelet antigens (HPAs) are associated with immune-mediated platelet disorders [75, 76]. 24 HPAs have been defined by serology 12 of which are grouped in 6 biallelic systems (HPA-1, HPA-2, HPA-3, HPA-4, HPA-5 and HPA-15) followed by either an ' $a$ ' for the more common allele or a ' $b$ ' for the less common allele [77]. The most well-known alloimmune thromboembolic disease is neonatal alloimmune thrombocytopenia (NATP), which is caused by passively transmitted maternal antibodies specific against paternally inherited fetal HPAs [78, 79]. The NATP is caused by fetomaternal mismatches of HPA-1 and HPA-5 in Caucasians and HPA-3 and HPA-4 in Asians [80, 81]. In our group, we developed a multiplexed assay using MALDI-TOF MS for simultaneously genotyping 6 HPAs and 12 alleles (HPA-1a/1b, HPA-2a/2b, HPA-3a/3b, HPA-4a/4b, HPA-5a/5b and HPA-15a/15b) in a single tube. We examined 120 donors by the multiplexed assay and compared the results generated by a sequence-specific primer PCR (SSP-PCR) and conventional sequencing. A $99.7-100 \%$ concordance for the genotyping of the 12 HPA alleles between the MALDI-TOF MS assay and conventional methods was achieved [47]. The multiplexed assay allows for the elimination of the time- and cost-consuming gel electrophoresis or fluorescent labelling. Our data suggests that this precise approach using cff-DNA may apply to NIPD for HPA genotyping regarding NATP.

\section{MALDI-TOF MS in Prenatal Diagnosis of Chromosomal Aneuploidy}

hME-based MALDI-TOF MS can be used to analyse copy number variation of each allele $[45,82,83]$. An allele-specific primer extension reaction designed by the hME to a heterozygous SNP generates two extension products, each has unique molecular weight, resulting in 2 peaks on MALDI- 
Fig. 2. MALDI-TOF MS in NIPD for aneuploidy using RNA-SNP. A Selection of a transcribed SNP locus on the chromosome of interest. B Selection of a placental specific mRNA. C RNA-SNP specific extension products analysed by MALDI-TOF MS.

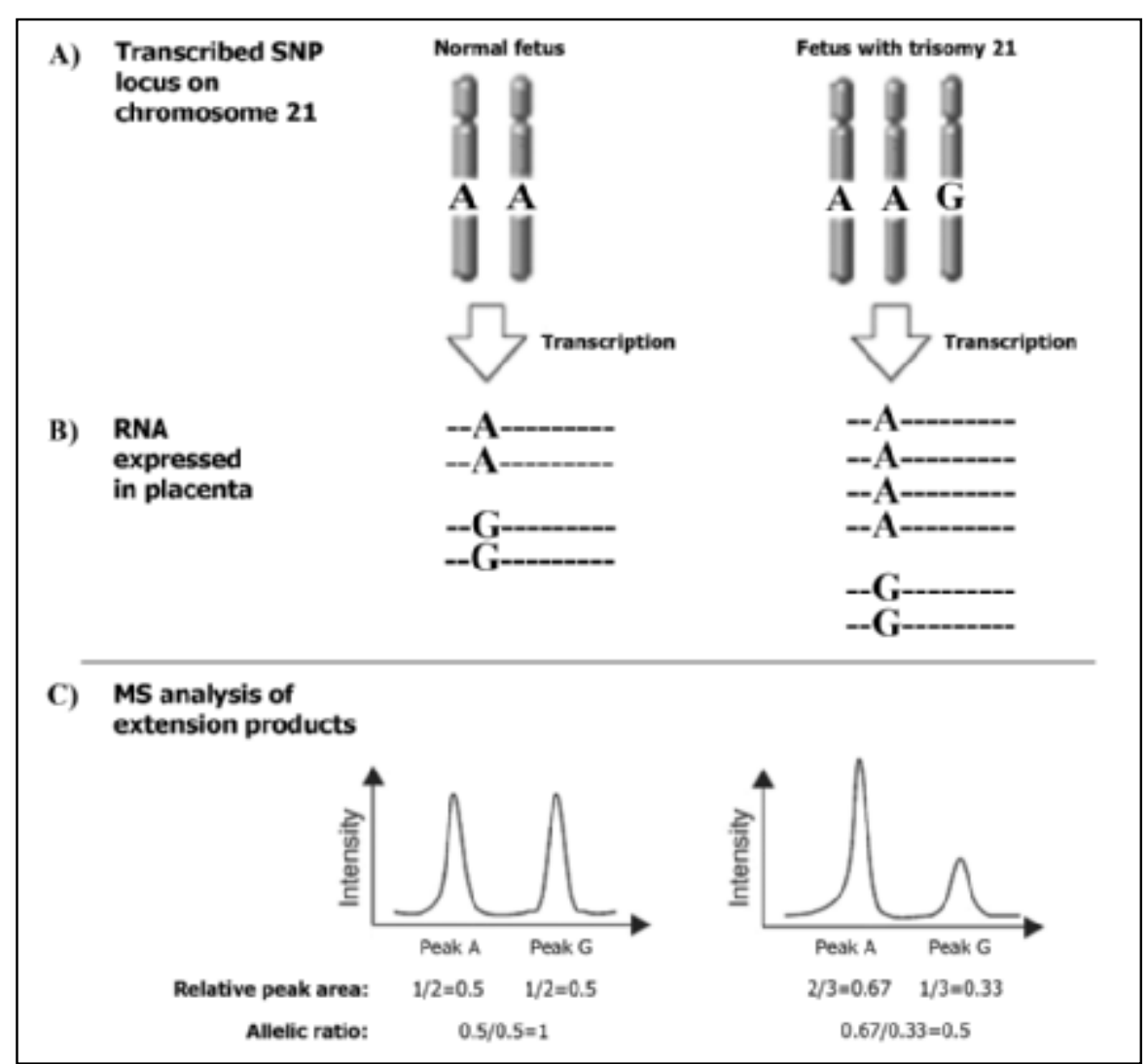

TOF MS. For every heterozygous SNP site, the intensity of the pair of mass signals are recorded and interpreted by MassARRAY ${ }^{\circledR}$ software (Sequenom). The relative quantification of copy number can be estimated through dividing the peak intensity generated from one allele by that of another allele. The ratios between two alleles are obtained as quantification of copy number variation. This concept can be applied for the detection of abnormalities in chromosome number. First, the company Sequenom investigated the feasibility of the concept to measure the allelic ratio of the chromosome 21 SNPs to identify trisomy 21 for prenatal diagnosis using the fetal genetic materials obtained by an invasive procedure. Heterozygous SNPs within the Down syndrome-critical region (DSCR) of chromosome 21 were selected for determining the chromosome ratios. The presence of a third copy could be identified by a deviation from the expected 1:1 allelic ratio in a euploid fetus as a 2:1 or a 1:2 ratio in trisomic fetus. Multiplex assays for a combination of 12 SNPs located within the region were performed on individuals of African, Asian, European, and Hispanic origin to analyse Down syndrome cell lines and chorionic villus samples containing trisomy 21 cases. An accuracy of $95 \%$ for discriminating trisomic and euploid DNA samples could be achieved by the preliminary study [84]. Subsequently, Tsui et al. [85] evaluated the use of the approach to identify trisomy 21 in various clinical samples, such as placenta, amniotic fluid and chorionic villus samples from normal and trisomy 21 cases. With no false-positive or false- negative results using more 'user-friendly' assays, the group recommended the approach as an alternative tool for prenatal diagnosis of trisomy 21; the approach is faster and more simple, and it has a high-throughput capacity compared to the conventional methods. To apply the approach for clinical use, our group performed a large-scale study on a cohort with 350 subjects [86]. Again, our data suggested that MALDI-TOF MS is a robust and reproducible method for the detection of trisomy 21 . In addition, we could also show that cff-DNA in amniotic fluid supernatants were useable to the identification. The only disadvantage compared with fluorescent in situ hybridization (FISH) and karyotyping was that the system could not promise the identification of a mosaic case [87].

The concept of measuring copy number variation within chromosome 21 for prenatal diagnosis of trisomy 21 using invasively obtained fetal genetic materials has been extended for developing NIPD using cell-free fetal genetic materials in maternal circulation in a risk-free application. Placentaspecific 4 (PLAC4) is expressed specifically in the placenta. The placenta-specific mRNA is transcribed from a gene located on chromosome 21. Placenta-derived PLAC4 can pass through the placenta and be released into maternal circulation. Molecular biological techniques allow precise quantification of PLAC4, which is absent in adult blood, in maternal circulation during pregnancy. Lo et al. [88] developed a RNA-SNP allelic ratio approach to determine the dosage of chromosome 21 using PLAC4 mRNA in maternal plasma 
(fig. 2). Heterozygous SNPs present in the coding region of the PLAC4 gene can be selected for this purpose. The presence of a third copy of chromosome 21 containing a heterozygous SNP could be identified by a deviation from the expected 1:1 ratio of PLAC4-SNP in a euploid fetus as a 2:1 or a 1:2 ratio in trisomic fetus. Using the MALDI-TOF MS, the RNA-SNP allelic ratio could be measured precisely for NIPD of trisomies. The approach was applied to maternal plasma analysis in 57 women carrying karyotypically normal fetuses with a mean gestation of 13 weeks and 10 women carrying trisomy-21 fetuses with a mean gestation of 14.7 weeks. A diagnostic sensitivity and specificity for trisomy 21 of 90 and $96.5 \%$ respectively could be achieved by the group [88]. This strategy could also be applied to trisomy 18 and 13 [89]. However, the limitation of this approach is that the diagnosis can only be performed for the pregnant women carrying fetuses containing heterozygous SNPs on coding regions of genes of interest. In addition, before processing the approach, informative heterozygous SNPs in the fetus should be obtained [88].

\section{MALDI-TOF MS in Identifying Fetal Gender- Independent Circulating Biomarkers}

Cff-DNA in maternal blood is associated with alteration of placental shedding. Elevated levels of cff-DNA in maternal circulation are seen with pathological pregnancies due to the increased cell turnover and/or impaired clearance [90, 91]. In preeclampsia, cff-DNA increased prior to its onset, and the levels corresponded to its severity, suggesting a protective diagnostic value for earlier diagnosis as well as for tailoring management of the patients [92-94]. In preterm labour, the levels of cff-DNA in maternal circulation could be used to distinguish between falsely and truly affected cases [95]. The results reveal the significance of transition from research findings to clinical practice. However, cff-DNA-based, non-invasive prenatal applications are limited by the lack of genderindependent fetal-specific genetic markers that would allow monitoring of all pregnancies [96]. Recently, a placenta-specific methylation profile has been suggested to serve as fetal gender-independent placental DNA marker to distinguish between fetal and maternal DNA in maternal circulation [97]. However, the use of this concept has been limited by the fact that no technique or general approach is superior for robust quantitative and sensitive analysis of methylation status [98, 99]. Sequenom's EpiTYPER ${ }^{\mathrm{TM}}$ assay created the opportunity for high-throughput quantitative analysis of DNA methylation status using MALDI-TOF MS with MassCLEAVE ${ }^{\mathrm{TM}}$ reagent, which is based on base-specific $(\mathrm{C} / \mathrm{T})$ cleavage reactions $[100,101]$. The robustness of the approach for quantifying methylated and unmethylated DNA has been evaluated by Sequenom [102] and also by our group [103]. The system enables combining quantitative, sensitive, automated, and high-throughput detection of methylation status in a single technique. Base-specific $(\mathrm{C} / \mathrm{T})$ cleavage reactions generate a cleaved $\mathrm{CpG}$ site, and the intensity of a pair of mass signals, one representing methylated and/or another one representing unmethylated DNA, can be recorded and interpreted by MassARRAY EpiTYPER software. The relative quantification of the methylation status can be estimated through dividing the peak intensity, or area of the methylated DNA, by the sum of the intensities or areas of the methylated and unmethylated components. The ratios between methylated and unmethylated DNA are obtained as quantification of methylation. In our group, we mixed fully methylated DNA into the pure unmethylated DNA in different ratios of 100:0, 50:50, $25: 75,5: 95$, and $0: 100$. The assay was able to discriminate the $5 \%$ methylated in $95 \%$ unmethylated components according to the ratios by the quantitative assay [103]. As little as $5 \mathrm{ng}$ of DNA per PCR reaction could guarantee the methylation analysis using the system. The approach may be applicable to develop methylation-based fetal gender-independent placental markers for NIPD.

SNPs occur in the genome frequently, with an average of one SNP found per kilobase. Paternally inherited SNPs, which can be robustly identified by primer extension reaction-based MALDI-TOF MS, may be useful to develop fetal gender-independent markers. In our group, we tested 41 SNP loci in 18 maternal plasma samples, 10 taken at term and 8 obtained early in the second trimester, using hME- and SABER-based MALDI-TOF MS combined with size fractionation. Ten paternally SNPs, rs1009789, rs109889, rs13234721, rs231146, rs30207, rs323421, rs405120, rs4778, rs547363 and rs776008, allowed us to distinguish between fetal and maternal cf-DNA for the 10 samples taken at term. The other eleven SNPs, rs109889, rs1475840, rs170183, rs2003624, rs222775, rs2835349, rs30207, rs375579, rs432137, rs732569 and rs776008, have been successfully used for detecting minority fetal in majority maternal components in the 8 samples obtained in the second trimester [49].

\section{Conclusion}

MALDI-TOF MS is completely automated for high-throughput analysis of as much as 384 samples running on one silicon chip. Developments of different protocols and assays enabled robust genotyping of single base difference, precise measuring of copy number variation, and quantitative methylation and expression analysis. Compared with conventional methods, the higher sensitivity of this approach offered opportunities for NIPD dealing with fetal genetic materials as minority mixed into maternal background molecules as majority. The high degree of multiplexing in one reaction makes the system cost-effective, fast, simple, and user friendly. However, the sophisticated and expensive equipment is recently not readily available to the majority of diagnostic or research laborato- 
ries. A single chip fixed with a curtain format for evaluating up to 384 samples makes single case detection, which is often seen in prenatal diagnosis, inflexible. In addition, NIPD of autosomal recessive homozygous disease as well as clinical application of NIPD for aneuploidies still remain considerably challenging.

\section{Acknowledgements}

This work was supported in part by Swiss National Science Foundation (320000-119722/1 and 320030-124958/1), Swiss Cancer League, Krebsliga Beider Basel, Dr Hans Altschueler Stiftung, Swisslife and Freiwillige Akademische Gesellschaft (FAK) in Basel.

We thank Mr. Ramin Radpour and Mrs. Corina Kohler for their excellent assistance and help. We are grateful to Miss Sheena Kinniry for proofreading the text.

\section{Disclosure}

The authors declared no conflict of interest.

\section{References}

1 Buckley F, Buckley SJ: Costs of prenatal genetic screening. Lancet 2008;372:1805.

2 Mathews,TJ, MacDorman MF: Infant mortality statistics from the 2005 period linked birth/infant death data set. Natl Vital Stat Rep 2008;57:1-32.

3 Kuppermann M, Norton ME: Prenatal testing guidelines: time for a new approach. Gynecol Obstet Invest 2005;60:6-10.

4 Schmid M, Drahonsky R, Fast-Hirsch C, Baumuhlner K, Husslein P, Blaicher W: Timing of referral for prenatal genetic counselling. Prenat Diagn 2009; 29:156-159.

5 Anderson CL, Brown CE: Fetal chromosomal abnormalities: antenatal screening and diagnosis. Am Fam Physician 2009;79:117-123.

6 Driscoll DA, Gross SJ: First trimester diagnosis and screening for fetal aneuploidy. Genet Med, 2008;10: $73-75$.

7 South ST, Chen Z, Brothman AR: Genomic medicine in prenatal diagnosis. Clin Obstet Gynecol 2008;51:62-73.

8 Evans MI, Andriole S: Chorionic villus sampling and amniocentesis in 2008. Curr Opin Obstet Gynecol 2008;20:164-168.

9 Forabosco A, Percesepe A, Santucci S: Incidence of non-age-dependent chromosomal abnormalities: a population-based study on 88965 amniocenteses. Eur J Hum Genet 2009;DOI: 10.1038/ejhg.2008.265.

10 Cohen SM, Yagel S: Evaluating the rate and risk factors for fetal loss after chorionic villus sampling. Obstet Gynecol 2009;113:437; author reply 437.

11 Li DK, Karlberg K, Wi S, Norem C: Factors influencing women's acceptance of prenatal screening tests. Prenat Diagn 2008;28:1136-1143.

12 Odibo AO, Dicke JM, Gray DL, Oberle B, Stamilio DM, Macones GA, Crane JP: Evaluating the rate and risk factors for fetal loss after chorionic villus sampling. Obstet Gynecol 2008;112:813-819.

-13 Odibo AO, Gray DL, Dicke JM, Stamilio DM, Macones GA, Crane JP: Revisiting the fetal loss rate after second-trimester genetic amniocentesis: a single center's 16-year experience. Obstet Gynecol 2008;111:589-595.

14 Yukobowich E, Anteby EY, Cohen SM, Lavy Y, Granat M, Yagel S: Risk of fetal loss in twin pregnancies undergoing second trimester amniocentesis(1). Obstet Gynecol 2001;98:231-234.

15 van de Vathorst S, Verhagen AA, Wildschut HI, Wolf H, Zeeman GG, Lind J: Termination of pregnancy after the 20-week ultrasonographic examination: haste and caution (in Netherlandish). Ned Tijdschr Geneeskd 2008;152:2589-2591.
6 Zeeman GG, Verhagen AA, Lind J, van de Vathorst S, Wildschut HI, Wolf H: Assessment of late pregnancy terminations, 2004-2007 (in Netherlandish). Ned Tijdschr Geneeskd, 2008;152:2632-2635.

17 Geifman-Holtzman O, Ober Berman J: Prenatal diagnosis: update on invasive versus noninvasive fetal diagnostic testing from maternal blood. Expert Rev Mol Diagn 2008;8:727-751.

18 Odibo AO, Stamilio DM, Nelson DB, Sehdev HM, Macones GA: A cost-effectiveness analysis of prenatal screening strategies for Down syndrome. Obstet Gynecol 2005;106:562-568.

19 Pitukkijronnakorn S, Manonai J, Chittacharoen A: Doctors' attitudes towards invasive prenatal diagnosis. J Obstet Gynaecol Res 2009;35:73-77.

20 Sparkes R, Johnson JA, Langlois S, Wilson RD, Allen V, Blight C, Desilets V, Gagnon A, Johnson JA, Langlois S, Summers A, Wyatt P: New molecular techniques for the prenatal detection of chromosomal aneuploidy. J Obstet Gynaecol Can 2008;30: 617-621, 622-627.

21 Hahn S, Zhong XY, Holzgreve W: Recent progress in non-invasive prenatal diagnosis. Semin Fetal Neonatal Med 2008;13:57-62.

22 Holzgreve W, Hahn S, Zhong XY, Lapaire O, Hosli I, Tercanli S, Mindy P: Genetic communication between fetus and mother: short- and long-term consequences. Am J Obstet Gynecol 2007;196:372-381.

23 Holzgreve W, Zhong,XY, Burk MR, Hahn S: Enrichment of fetal cells and free fetal DNA from maternal blood: an insight into the Basel experience. Early Pregnancy 2001;5:43-44.

24 Krabchi K, Gros-Louis F, Yan J, Bronsard M, Masse J, Forest JC, Drouin R: Quantification of all fetal nucleated cells in maternal blood between the 18 th and 22nd weeks of pregnancy using molecular cytogenetic techniques. Clin Genet 2001;60:145-150.

25 Torricelli F, Pescucci C: Isolation of fetal cells from the maternal circulation: prospects for the non-invasive prenatal diagnosis. Clin Chem Lab Med 2001;39: 494-500.

26 Bianchi DW, Simpson JL, Jackson LG, Elias S, Holzgreve W, Evans MI, Dukes KA, Sullivan LM, Klinger KW, Bischoff FZ, Hahn S, Johnson KL, Lewis D, Wapner RJ, de la Cruz F: Fetal gender and aneuploidy detection using fetal cells in maternal blood: analysis of NIFTY I data. National Institute of Child Health and Development Fetal Cell Isolation Study. Prenat Diagn 2002;22:609-615.

27 Troeger C, Zhong XY, Burgemeister R, Minderer S, Tercanli S, Holzgreve W, Hahn S: Approximately half of the erythroblasts in maternal blood are of fetal origin. Mol Hum Reprod 1999;5:1162-1165.
8 Babochkina T, Mergenthaler S, Dinges TM, Holzgreve W, Hahn S: Direct detection of fetal cells in maternal blood: a reappraisal using a combination of two different Y chromosome-specific FISH probes and a single $\mathrm{X}$ chromosome-specific probe. Arch Gynecol Obstet 2005;273:166-119.

29 Lo YM, Corbetta N, Chamberlain PF, Rai V, Sargent IL, Redman CW, Wainscoat JS: Presence of fetal DNA in maternal plasma and serum. Lancet 1997; 350:485-487.

30 Zhong XY, Holzgreve W, Hahn S: Cell-free fetal DNA in the maternal circulation does not stem from the transplacental passage of fetal erythroblasts. Mol Hum Reprod 2002;8:864-870.

31 Zhong XY, Holzgreve W, Hahn S: Direct quantification of fetal cells in maternal blood by real-time PCR. Prenat Diagn 2006;26:850-854.

32 Zhong XY, Holzgreve W, Li JC, Aydinli K, Hahn $\mathrm{S}$ : High levels of fetal erythroblasts and fetal extracellular DNA in the peripheral blood of a pregnant woman with idiopathic polyhydramnios: case report. Prenat Diagn 2000;20:838-841.

33 Zhong XY, Steinborn A, Sohn C, Holzgreve W, Hahn S: High levels of circulatory erythroblasts and cell-free DNA prior to intrauterine fetal death. Prenat Diagn 2006;26:1272-1273.

34 Lo YM, Zhang J, Leung TN, Lau TK, Chang AM, Hjelm NM: Rapid clearance of fetal DNA from maternal plasma. Am J Hum Genet 1999;64:218-224.

35 Zhong XY, Holzgreve W, Hahn S: Risk free simultaneous prenatal identification of fetal Rhesus D status and sex by multiplex real-time PCR using cell free fetal DNA in maternal plasma. Swiss Med Wkly 2001;131:70-74.

36 Costa JM, Benachi A, Gautier E, Jouannic JM, Ernault P, Dumez Y: First-trimester fetal sex determination in maternal serum using real-time PCR. Prenat Diagn 2001;21:1070-1074.

37 Daniels G, Finning K, Martin P, Massey E: Noninvasive prenatal diagnosis of fetal blood group phenotypes: current practice and future prospects. Prenat Diagn 2009;29:101-107.

38 Benachi A, Costa JM: Non-invasive prenatal diagnosis of fetal aneuploidies. Lancet 2007;369:440-442.

39 Zhong XY, Burk MR, Troeger C, Jackson LR, Holzgreve W, Hahn S: Fetal DNA in maternal plasma is elevated in pregnancies with aneuploid fetuses. Prenat Diagn 2000;20:795-798.

-40 Li Y, Di Naro E, Vitucci A, Zimmermann B, Holzgreve W, Hahn S: Detection of paternally inherited fetal point mutations for beta-thalassemia using size-fractionated cell-free DNA in maternal plasma. JAMA 2005;293:843-849. 
41 Chiu NH, Cantor CR: Mass spectrometry of nucleic acids. Clin Chem 1999;45:1578.

42 Nelson MR, Marnellos G, Kammerer S, Hoyal CR, Shi MM, Cantor CR, Braun A: Large-scale validation of single nucleotide polymorphisms in gene regions. Genome Res 2004;14:1664-1668.

43 Cullinan A, Cantor C: Sequenom, Inc. Pharmacogenomics 2008;9:1211-1215.

44 Li Y, Holzgreve W, Kiefer V, Hahn S: MALDITOF mass spectrometry compared with real-time PCR for detection of fetal cell-free DNA in maternal plasma. Clin Chem 2006;52:2311-2312.

45 McCullough RM, Cantor CR, Ding C: Highthroughput alternative splicing quantification by primer extension and matrix-assisted laser desorption/ionization time-of-flight mass spectrometry. Nucleic Acids Res 2005;33:e99.

46 Xiu-Cheng Fan A, Garritsen HS, Tarhouny SE, Morris M, Hahn S, Holzgreve W,Zhong XY: A rapid and accurate approach to identify single nucleotide polymorphisms of mitochondrial DNA using MALDI-TOF mass spectrometry. Clin Chem Lab Med 2008;46:299-305.

47 Garritsen HS, Fan AX, Bosse N, Hannig H, Kelsch R, Kroll H, Holzgreve W, Zhong XY: Matrix-assisted laser desorption/ionization time-of-flight mass spectrometry for genotyping of human platelet-specific antigens. Transfusion 2009;49:252-258.

48 Ding C: Maldi-TOF mass spectrometry for analyzing cell-free fetal DNA in maternal plasma. Methods Mol Biol 2008;444:253-627.

49 Ding C, Chiu RW, Lau TK, Leung TN, Chan LC, Chan AY, Charoenkwan P, Ng IS, Law HY, Ma ES $\mathrm{Xu}$ X, Wanapirak C, Sanguansermsri T, Liao C, Ai MA, Chui DH, Cantor CR, Lo YM: MS analysis of single-nucleotide differences in circulating nucleic acids: Application to noninvasive prenatal diagnosis. Proc Natl Acad Sci U S A 2004;101:10762-10767.

49 Li Y, Wenzel F, Holzgreve W, Hahn S: Genotyping fetal paternally inherited SNPs by MALDI-TOF MS using cell-free fetal DNA in maternal plasma: influence of size fractionation. Electrophoresis 2006;27: 3889-3896.

50 Ding C, Lo YM: MALDI-TOF mass spectrometry for quantitative, specific, and sensitive analysis of DNA and RNA. Ann N Y Acad Sci 2006;1075:282287.

51 Kobayashi D, Satsuma S: Bone dysplasia with short limb (in Japanese). Clin Calcium 2008;18:1786-1791.

-52 Li Y, Holzgreve W, Page-Christiaens GC, Gille JJ, Hahn S: Improved prenatal detection of a fetal point mutation for achondroplasia by the use of size-fractionated circulatory DNA in maternal plasma--case report. Prenat Diagn 2004;24:896-898.

53 Li Y, Page-Christiaens GC, Gille JJ, Holzgreve W, Hahn S: Non-invasive prenatal detection of achondroplasia in size-fractionated cell-free DNA by MALDI-TOF MS assay. Prenat Diagn 2007;27: $11-17$.

54Chiu RW, Lo YM: Recent developments in fetal DNA in maternal plasma. Ann N Y Acad Sci, 2004;1022: 100-104.

55 Chiu RW, Lau TK, Cheung PT, Gong ZQ, Leung TN, Lo,YM: Noninvasive prenatal exclusion of congenital adrenal hyperplasia by maternal plasma analysis: a feasibility study. Clin Chem 2002;48:778-780.

56 Chiu RW, Lau TK, Leung TN, Chow KC, Chui DH, Lo YM: Prenatal exclusion of beta thalassaemia major by examination of maternal plasma. Lancet 2002;360:998-1000.

57 Nikuei P, Hadavi V, Rajaei M, Saberi M, Hajizade F, Najmabadi H: Prenatal diagnosis for beta-thalassemia major in the Iranian Province of Hormozgan. Hemoglobin 2008;32:539-545.
58 Steinberg MH: Sickle cell anemia, the first molecular disease: overview of molecular etiology, pathophysiology, and therapeutic approaches. ScientificWorldJournal 2008;8:1295-1324.

59 Steinberg MH: Genetic etiologies for phenotypic diversity in sickle cell anemia. ScientificWorldJournal 2009:9:46-67.

60 Rund D, Fucharoen S: Genetic modifiers in hemoglobinopathies. Curr Mol Med 2008;8:600-608.

61 Bonis PA: Clinical outcomes after hepatitis C infection from contaminated anti-D immune globulin. $\mathrm{N}$ Engl J Med 1999;341:763.

62 Patole S, Vijayakumar P, Jog S: Perinatal immunomodulation. J Matern Fetal Neonatal Med 2002;11: 290-301.

63 Pilgrim H, Lloyd-Jones M, Rees A: Routine antenatal anti-D prophylaxis for $\mathrm{RhD}$-negative women: a systematic review and economic evaluation. Health Technol Assess 2009;13:1-126.

64 Crombach G, Picard F, Beckmann M, Tutschek B, Bald R, Niederacher D: Fetal Rhesus D genotyping on amniocytes in alloimmunised pregnancies using fluorescence duplex polymerase chain reaction. $\mathrm{Br}$ J Obstet Gynaecol 1997;104:15-19.

65 Crombach G, Picard F, Beckmann MW, Niederacher D, Bender HG: Prenatal determination of fetal rhesus factor in amnionic cells using polymerase chain reaction (in German). Geburtshilfe Frauenheilkd 1995;55:577-579.

66 Moise KJ Jr: Management of rhesus alloimmunization in pregnancy. Obstet Gynecol 2008;112: 164-176.

67 van der Schoot CE, Hahn S, Chitty LS: Non-invasive prenatal diagnosis and determination of fetal $\mathrm{Rh}$ status. Semin Fetal Neonatal Med 2008;13:63-68.

68 Avent ND: RHD genotyping from maternal plasma: guidelines and technical challenges. Methods Mol Biol 2008;444:185-201.

69 Grill S, Banzola I, Li Y, Rekhviashvili T, Legler TJ, Muller SP, Zhong XY, Hahn S, Holzgreve W: High throughput non-invasive determination of foetal Rhesus D status using automated extraction of cellfree foetal DNA in maternal plasma and mass spectrometry. Arch Gynecol Obstet 2009;279:533-537.

70 Araujo F, Pereira C, Monteiro F, Henriques I, Meireles E, Lacerda P, Aleixo A, Rodrigues MJ, Celeste R, Cunha-Ribeiro LM: Blood group antigen profile predicted by molecular biology-use of real-time polymerase chain reaction to genotype important KEL, JK, RHD, and RHCE alleles. Immunohematology 2002;18:59-64.

71 Finning K, Martin P, Summers J, Daniels G: Fetal genotyping for the $\mathrm{K}$ (Kell) and $\mathrm{Rh} \mathrm{C}$, c, and $\mathrm{E}$ blood groups on cell-free fetal DNA in maternal plasma. Transfusion 2007;47:2126-2133.

72 Moise KJ: Fetal anemia due to non-Rhesus-D redcell alloimmunization. Semin Fetal Neonatal Med, 2008;13:207-214.

73 Zupanska B, Nowaczek-Migas M, Michalewska B, Wielgos M, Orzinska A: Anti-K antibodies in pregnant women and genotyping of $\mathrm{K}$ antigen in foetuses(in Polish). Ginekol Pol, 2008;79:410-414.

74 Li Y, Finning K, Daniels G, Hahn S, Zhong X, Holzgreve W: Noninvasive genotyping fetal Kell blood group (KEL1) using cell-free fetal DNA in maternal plasma by MALDI-TOF mass spectrometry. Prenat Diagn 2008;28:203-208.

75 Lemnrau AG, Cardoso S, Creary LE, Brown C, Miretti M, Girdlestone J, Navarrete CV: Human platelet antigen typing of neonatal alloimmune thrombocytopenia patients using whole genome amplified DNA and a 5'-nuclease assay. Transfusion 2009; 49:953-958.
6 Thude H, Gatzka E, Anders O, Barz D: Allele frequencies of human platelet antigen $1,2,3$, and 5 systems in patients with chronic refractory autoimmune thrombocytopenia and in normal persons. Vox Sang 1999;77:149-153.

77 Curtis BR: Genotyping for human platelet alloantigen polymorphisms: applications in the diagnosis of alloimmune platelet disorders. Semin Thromb Hemost 2008;34:539-548.

78 Castro V, Kroll H, Origa AF, Falconi MA, Marques SB, Marba ST, Passini R Jr, AnnichinoBizzacchi JM, Costa FF, Santoso S, Arruda VR: A prospective study on the prevalence and risk factors for neonatal thrombocytopenia and platelet alloimmunization among 9332 unselected Brazilian newborns. Transfusion, 2007;47:59-66.

79 Glade-Bender J, McFarland JG, Kaplan C, Porcelijn L, Bussel JB: Anti-HPA-3A induces severe neonatal alloimmune thrombocytopenia. J Pediatr 2001;138:862-867.

80 Ahya R, Turner ML, Urbaniak SJ: Fetomaternal alloimmune thrombocytopenia. Transfus Apher Sci 2001;25:139-145.

81 Zhang KQ, Wang B, Wang ZL, Li Y: Analysis of human platelet antigen genotypic frequencies in Chinese population by PCR amplification with sequence specific primers. Zhongguo Shi Yan Xue Ye Xue Za Zhi, 2001;9:256-259.

82 Amexis G, Oeth P, Abel K, Ivshina A, Pelloquin F, Cantor CR, Braun A, Chumakov K: Quantitative mutant analysis of viral quasispecies by chip-based matrix-assisted laser desorption/ionization time-offlight mass spectrometry. Proc Natl Acad Sci U S A 2001:98:12097-12102.

83 Jurinke C, Denissenko,MF, Oeth P, Ehrich M, van den Boom D, Cantor CR: A single nucleotide polymorphism based approach for the identification and characterization of gene expression modulation using MassARRAY. Mutat Res 2005;573:83-95.

84 Nelson MR, Whitacre JL, Oeth P, Kammerer S, Brambati B, Tului L, Milunsky A, Braun A: Rapid diagnostic test for trisomy 21 and other aneuploidies using mass spectrometry. ACMG, Chicago, IL, USA, June, 3-5, 2005.

85 Tsui NB, Chiu RW, Ding C, El-Sheikhah A, Leung TN, Lau TK, Nicolaides KH, Lo YM: Detection of trisomy 21 by quantitative mass spectrometric analysis of single-nucleotide polymorphisms. Clin Chem, 2005;51:2358-2362.

86 Huang DJ, Nelson MR, Zimmermann B, Dudarewicz L, Wenzel F, Spiegel R, Nagy B, Holzgreve W, Hahn S: Reliable detection of trisomy 21 using MALDI-TOF mass spectrometry. Genet Med 2006; 8:728-734.

87 Huang DJ, Nelson MR, Holzgreve W: Maldi-TOF mass spectrometry for trisomy detection. Methods Mol Biol 2008;444:123-132.

88 Lo YM, Tsui NB, Chiu RW, Lau TK, Leung TN, Heung MM, Gerovassili A, Jin Y, Nicolaides KH, Cantor CR, Ding C: Plasma placental RNA allelic ratio permits noninvasive prenatal chromosomal aneuploidy detection. Nat Med 2007;13:218-223.

89 Tang M, Lee M, Mohsenian F, Tao Shi T, Dragon B, Ding JH, Yang YF: Identification of RNASNP markers for noninvasive prenatal diagnosis (NIPD) of T18 and T13. Am J Obstet Gynecol 2008;199(supppl 1):S163.

90 Gupta AK, Rusterholz C, Huppertz B, Malek A, Schneider H, Holzgreve W, Hahn S: A comparative study of the effect of three different syncytiotrophoblast micro-particles preparations on endothelial cells. Placenta 2005;26:59-66. 
91 Lau TW, Leung TN, Chan LY, Lau TK, Chan KC, Tam WH, Lo YM: Fetal DNA clearance from maternal plasma is impaired in preeclampsia. Clin Chem 2002;48:2141-2146.

92 Zhong XY, Holzgreve W, Hahn S: The levels of circulatory cell free fetal DNA in maternal plasma are elevated prior to the onset of preeclampsia. Hypertens Pregnancy 2002;21:77-83.

93 Zhong XY, Laivuori H, Livingston JC, Ylikorkala O, Sibai BM, Holzgreve W, Hahn S: Elevation of both maternal and fetal extracellular circulating deoxyribonucleic acid concentrations in the plasma of pregnant women with preeclampsia. Am J Obstet Gynecol 2001;184:414-419.

94 Zhong XY, Wang Y, Chen S, Pan X, Zhu N, Hahn C, Huppertz B, Holzgreve W,Hahn S: Circulating fetal DNA in maternal plasma is increased in pregnancies at high altitude and is further enhanced by preeclampsia. Clin Chem, 2004;50:2403-2405.

95 Leung TN, Zhang J, Lau TK, Hjelm NM, Lo YM: Maternal plasma fetal DNA as a marker for preterm labour. Lancet 1998;352:1904-1905.
96 Zhong XY, Hahn S, Holzgreve W: Prenatal identification of fetal genetic traits. Lancet 2001;357: 310-311.

97 Chim SS, Tong YK, Chiu RW, Lau TK, Leung TN, Chan LY, Oudejans CB, Ding C, Lo YM: Detection of the placental epigenetic signature of the maspin gene in maternal plasma. Proc Natl Acad Sci U S A 2005;102:14753-14758.

98 Cottrell SE, Laird PW: Sensitive detection of DNA methylation. Ann N Y Acad Sci 2003;983:120-130.

99 Laird PW: The power and the promise of DNA methylation markers. Nat Rev Cancer 2003;3:253266.

100 Ehrich M, Nelson MR, Stanssens P, Zabeau M, Liloglou T, Xinarianos G, Cantor CR, Field JK, van den Boom D: Quantitative high-throughput analysis of DNA methylation patterns by basespecific cleavage and mass spectrometry. Proc Natl Acad Sci U S A 2005;102:15785-15790.
101 Stanssens P, Zabeau M, Meersseman G, Remes G, Gansemans Y, Storm N, Hartmer R, Honisch C, Rodi CP, Bocker S, van den Boom, D: Highthroughput MALDI-TOF discovery of genomic sequence polymorphisms. Genome Res, 2004;14: 126-133.

102 Ehrich M, Turner J, Gibbs P, Lipton L, Giovanneti M, Cantor C, van den Boom D: Cytosine methylation profiling of cancer cell lines. Proc Natl Acad Sci U S A 2008;105:4844-4849.

103 Radpour R, Haghighi MM, Fan AX, Torbati PM Hahn S, Holzgreve W, Zhong XY: High-throughput hacking of the methylation patterns in breast cancer by in vitro transcription and thymidinespecific cleavage mass array on MALDI-TOF Silico-Chip. Mol Cancer Res, 2008:6:1702-1709. 